\title{
AMP-activated protein kinase kinase activity and phosphorylation of AMP-activated protein kinase in contracting muscle of sedentary and endurance trained rats
}

Denise Hurst

Brigham Young University - Provo

Follow this and additional works at: https://scholarsarchive.byu.edu/etd

Part of the Cell and Developmental Biology Commons, and the Physiology Commons

BYU ScholarsArchive Citation

Hurst, Denise, "AMP-activated protein kinase kinase activity and phosphorylation of AMP-activated protein kinase in contracting muscle of sedentary and endurance trained rats" (2007). Theses and Dissertations. 987.

https://scholarsarchive.byu.edu/etd/987

This Thesis is brought to you for free and open access by BYU ScholarsArchive. It has been accepted for inclusion in Theses and Dissertations by an authorized administrator of BYU ScholarsArchive. For more information, please contact scholarsarchive@byu.edu, ellen_amatangelo@byu.edu. 


\title{
AMP-ACTIVATED PROTEIN KINASE KINASE ACTIVITY AND PHOSPHORYLATION OF AMP-ACTIVATED PROTEIN \\ KINASE IN CONTRACTING MUSCLE OF SEDENTARY AND ENDURANCE- \\ TRAINED RATS
}

\author{
by \\ Denise Hurst \\ A thesis submitted to the faculty of \\ Brigham Young University \\ in partial fulfillment of the requirements for the degree of
}

Master of Science

Department of Physiology and Developmental Biology

Brigham Young University

August 2007 


\title{
BRIGHAM YOUNG UNIVERSITY
}

\section{GRADUATE COMMITTEE APPROVAL}

\author{
of a thesis submitted by
}

Denise Hurst

This thesis has been read by each member of the following graduate committee and by majority vote has been found to be satisfactory.

Date

Date

Date
William W. Winder, Chair

Allan M. Judd

Allen C. Parcell 


\section{BRIGHAM YOUNG UNIVERSITY}

As the chair of the candidate's graduate committee, I have read the thesis of Denise Hurst in its final form and have found that (1) its format, citations, and bibliographical style are consistent and acceptable and fulfill university and department style requirements; (2) its illustrative materials including figures, tables, and charts are in place; and (3) the final manuscript is satisfactory to the graduate committee and is ready for submission to the university library.

Date

Accepted for the Department
William W. Winder

Chair, Graduate Committee
Dixon J. Woodbury

Graduate Coordinator

Accepted for the College

Rodney J. Brown

Dean, College of Biology and Agriculture 


\author{
ABSTRACT \\ AMP-ACTIVATED PROTEIN KINASE KINASE ACTIVITY AND \\ PHOSPHORYLATION OF AMP-ACTIVATED PROTEIN \\ KINASE IN CONTRACTING MUSCLE OF \\ SEDENTARY AND ENDURANCE- \\ TRAINED RATS \\ Denise Hurst \\ Department of Physiology and Developmental Biology \\ Master of Science
}

This study was designed to examine activity of AMP-activated protein kinase kinase (AMPKK) and AMP-activated protein kinase (AMPK) in muscles from control (C) and endurance trained (T) rats. Rats were trained 5 days/wk, $2 \mathrm{hr} / \mathrm{d}$ for $8 \mathrm{wks}$ at a final intensity of $32 \mathrm{~m} / \mathrm{min}$ up a $15 \%$ grade with 30 second sprints at $52 \mathrm{~m} / \mathrm{min}$ every 10 min. Gastrocnemius muscles were stimulated in situ in $\mathrm{T}$ and $\mathrm{C}$ rats for $5 \mathrm{~min}$ at frequencies of $0.4 / \mathrm{sec}$ and $1 / \mathrm{sec}$. Gastrocnemius LKB1 protein, a putative component of the AMPKK complex (LKB1, STRAD, and MO25), increased approximately 2-fold in response to training. Phosphorylation of AMPK determined by western blot was increased at both stimulation rates in both control and trained rats. AMPK activity of 
both the $\alpha_{1}$ and $\alpha_{2}$ isoforms (immunoprecipitates) also increased at both stimulation rates in both $\mathrm{C}$ and $\mathrm{T}$ rats. AMPKK activity was strikingly lower in both resuspended polyethylene glycol (PEG) precipitates and $1200 \mathrm{x}$ g supernatant of the crude homogenate of muscle extracts from the trained compared to control rats. AMPKK activity did not increase in either $\mathrm{T}$ or $\mathrm{C}$ in response to electrical stimulation even though phospho-AMPK did increase. Interestingly, AMPKK activity in the $1200 \mathrm{xg}$ supernatant of the crude homogenate actually decreased upon stimulation in the control rats. These results suggest that AMPKK is activated during electrical stimulation by mechanisms other than covalent modification. Possibilities include AMP-induced optimization of the phosphorylation site on the target protein, contraction-induced changes in undefined allosteric modulators, and contraction-induced association with other proteins. (Study approved by the IACUC and supported by NIH RO1 AR41438.) 



\section{ACKNOWLEDGMENTS}

I would like to thank the members of my committee, especially Dr. William W. Winder for his guidance and patience for the duration of research and writing. I would also like to thank all the members of the lab including Eric Taylor, Troy Cline, Lyle Greenwood, Cori Compton, and Jeremy Lamb. I also thank my family and close

friends for their endless support and encouragement. This work was supported by the National Institutes of Health Grant AR-41438. 


\section{TABLE OF CONTENTS}

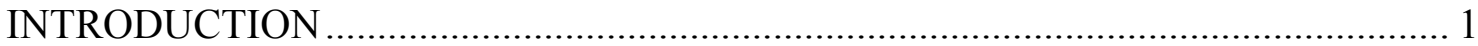

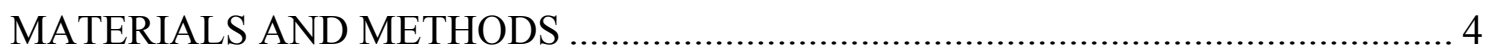

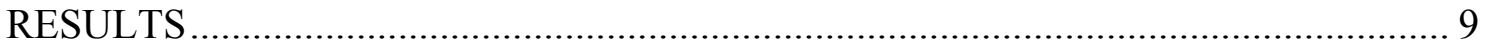

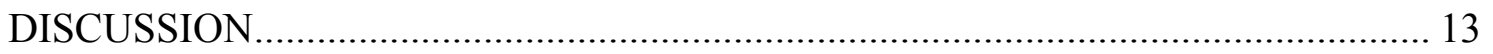

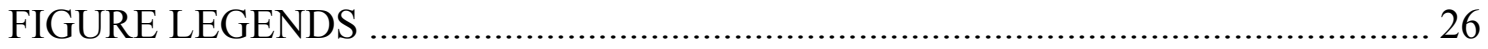




\section{LIST OF FIGURES}

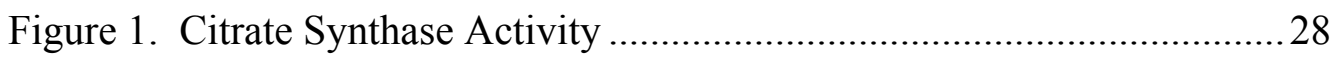

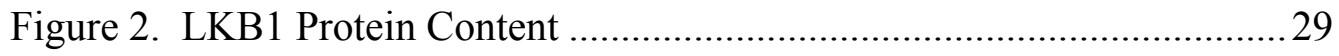

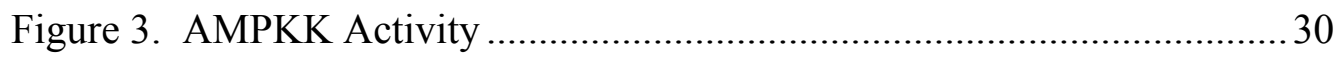

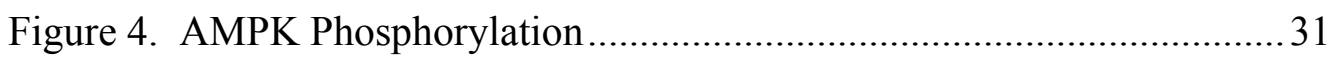

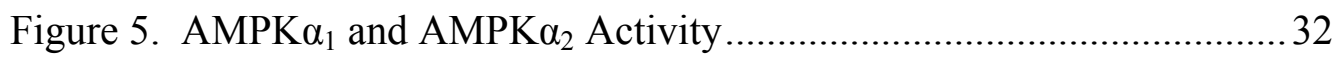

Figure 6. Acetyl-CoA Carboxylase (ACC) Activity and Phosphorylation ..... 33

Figure 7. Phosphocreatine (PCr) and Glycogen Concentrations .....................34

Figure 8. ATP and Lactate Concentrations ............................................. 35 


\section{INTRODUCTION}

The AMP-activated protein kinase (AMPK) is a key monitor and regulator of cellular energy status $(20,21,40,42)$. AMPK is activated by cellular stresses that increase the cellular AMP: ATP ratio; this decreased cellular energy charge may come as a result of hypoxia, pharmacological agents, low glucose, or muscle contraction (20, 21, 40, 42). When activated, AMPK phosphorylates multiple downstream targets to activate catabolic pathways (ATP-replenishing) and inhibit anabolic pathways (ATPdepleting) $(20,21,40,42)$. AMPK phosphorylates targets involved in protein synthesis $(10,45)$, glucose metabolism $(17,23)$, and lipid metabolism $(2,10,27,28,39,41)$.

AMPK is a heterotrimeric protein complex consisting of one each of the $\alpha, \beta$, and $\gamma$ subunits (34). Each subunit exists as multiple isoforms, including $\alpha 1, \alpha 2, \beta 1, \beta 2$, $\gamma 1, \gamma 2$, and $\gamma 3(4,9,34)$. The $\beta$ and $\gamma$ subunits are noncatalytic and contain domains involved in regulation and localization of $\operatorname{AMPK}(4,9)$. The $63 \mathrm{kD} \alpha$ subunit is the catalytic subunit and exists as two isoforms $\alpha_{1}$ and $\alpha_{2}(34)$. The $\alpha_{1}$ and $\alpha_{2}$ subunits both contain a threonine at residue 172 with identical surrounding sequence indicating similar phosphorylation and regulation by the upstream kinase(s) which are collectively called AMP-activated protein kinase kinase $(\mathrm{AMPKK})(15,34,43)$. Phosphorylation of AMPK by AMPKK on Thr172 of the alpha subunit is necessary for full activation and kinase activity; activation of AMPK may be as much as 50-fold due to phosphorylation $(15,35,43)$.

After a long search, LKB1 in complex with MO25 and STRAD has been identified as a major upstream kinase in the AMPK cascade in liver $(14,27,32,44)$. Recent studies using muscle-specific LKB1 knockout mice show decreases in basal and 
induced AMPK activation and phosphorylation, a reduction in mitochondrial oxidative enzymes, decreased contraction-induced glucose uptake $(22,30,31,38)$.

Skeletal muscle contraction results in increased activation of AMPK and phosphorylation of AMPK at Thr172 $(7,25,26,28)$. This increase in phospho-AMPK suggests an increase in the activity of the upstream kinase, AMPKK. The mechanisms that increase AMPKK activity as a result of muscle contraction are unclear. This study was designed to determine if contraction-induced increases in AMPKK activity can be detected in in vitro assays of AMPKK fractions isolated from gastrocnemius muscle and if this activation is similar between trained and control rats at different rates of electrical stimulation. Activating modifications of AMPKK that would be detected in in vitro assays include covalent modifications (phosphorylation/dephosphorylation) and stable association/disassociation with other proteins. If an increase in AMPKK activity is not detected in in vitro assays, the activation may result from allosteric modulation (AMP, phosphocreatine, glycogen, etc), transient association with other proteins, or changes in cellular localization. It is also possible that AMPKK is constitutively active and increased phosphorylation of AMPK as a result of contraction is due solely to allosteric enhancement of AMPK as a substrate.

Several studies have noted that phosphorylation and activation of skeletal muscle AMPK in response to muscle contraction is decreased after endurance-training $(7,25)$. This attenuation could be due to several adaptations resulting from endurancetraining, including increased oxidative capacity and increased energy storage. It is also possible that the reduction of AMPK responsiveness to contraction is due to direct changes such as alterations in AMPK isoform expression $(7,25)$. 
We hypothesized that AMPKK activity would be increased in in vitro assays on AMPKK fractions from electrically-stimulated gastrocnemius (as a result of covalent modification or stable protein interactions). Additionally, we predicted that AMPKK activation after stimulation would be lower in muscles from endurance-trained rats than in their control counterparts since AMPK activation in response to muscle contraction appears to be attenuated after endurance-training $(7,25)$. 


\section{MATERIALS AND METHODS}

Animal Care and Training Protocol. All animal procedures were approved by the Institutional Animal Care and Use Committee of Brigham Young University. Male Sprague-Dawley Rats (Sasco, Wilmington, MA) were housed singly in a temperature controlled room $\left(21^{\circ} \mathrm{C}\right)$ with a 12-hour light-dark cycle. Rats were assigned to either a trained (T) or non-trained (NT) group. Trained rats ran on motor-driven rodent treadmills at a $15 \%$ grade 5 days/wk in a room cooled to $16^{\circ} \mathrm{C}$. Training rats ran at increasing intensity for at least eight weeks and were maintained at the highest intensity for at least the final 2 weeks before sacrifice (total of 10-11 weeks). The initial training intensity was two $45-\mathrm{min}$ exercise bouts at $16 \mathrm{~m} / \mathrm{min}$. The final training intensity was a single 120 -min exercise bout at $32 \mathrm{~m} / \mathrm{min}$ with $30 \mathrm{sec}$ sprints at $53 \mathrm{~m} / \mathrm{min}$ every $10 \mathrm{~min}$. Trained rats were provided with Harland Teklad rat chow ad libitum; non-trained rats received the same diet in restricted amounts to maintain body weights similar to those of the trained group. At the time of sacrifice, trained rats weighed $356 \pm 13 \mathrm{~g}$ and nontrained rats weighed $353 \pm 13 \mathrm{~g}$ (no significant difference, $\mathrm{P}<0.05$ ). A previous study found untrained rats fed ad libitum and untrained food-restricted rats to have similar AMPK activities (8).

In situ stimulation of the gastrocnemius muscle. On the day of sacrifice, rats were anesthetized by intraperitoneal injection of sodium pentobarbital ( $50 \mathrm{mg} / \mathrm{kg}$ body weight). Trained rats were anesthetized 18-24 hours after the last exercise bout. Rats were maintained under anesthesia for at least $45 \mathrm{~min}$ before surgery to ensure any rise in AMPK activity as a result of handling had subsided. The tibial nerve was exposed surgically and attached to an electrode. Gastrocnemius muscles were electrically 
stimulated via the tibial nerve with $10 \mathrm{~ms}$ pulses at $4 \mathrm{~V}$ for $5 \mathrm{~min}$ at frequencies of .4 and $1 / \mathrm{sec}$. After stimulation, muscles were rapidly removed, clamp-frozen between stainless steel clamps at liquid nitrogen temperature, and stored at $-95^{\circ} \mathrm{C}$ until analysis.

Tissue Homogenization. Muscles were ground to powder at liquid nitrogen temperature using ceramic mortars and pestles. One part tissue was homogenized thoroughly with 9 parts buffer using a glass homogenizer. Unless otherwise noted, the following homogenization buffer was used: $50 \mathrm{mM}$ Tris-HCl, $250 \mathrm{mM}$ Mannitol, 50 mM NaF, 5mM Sodium Pyrophosphate, 1 mM EDTA, 1 mM EGTA, 1\% Triton X-100, $1 \mathrm{mM}$ Dithiothreitol, $1 \mathrm{mM}$ Benzamidine, $0.1 \mathrm{mM}$ Phenylmethane sulfonyl fluoride (PMSF), $5 \mu \mathrm{g} / \mathrm{ml}$ soybean trypsin inhibitor (SBTI), adjusted to $\mathrm{pH} 7.4$ and cooled to $4^{\circ} \mathrm{C}$. DTT, Benzamidine, PMSF, and SBTI were added immediately prior to tissue homogenization. Tissue homogenates were then centrifuged at $1200 \mathrm{x} \mathrm{g}$ for $10 \mathrm{~min}$ to remove connective tissue.

Citrate Synthase Activity Assay. Enzyme activity assays for Citrate Synthase were done on preparations of $10 \%(\mathrm{w} / \mathrm{v})$ tissue homogenates in Homogenization Buffer. Homogenates underwent three freeze-thaw cycles prior to being assayed for citrate synthase activity using the method of Srere (33).

AMPKK and AMPK Activity Assays. Enzyme activity assays for AMPKK were done using preparations of $10 \%(\mathrm{w} / \mathrm{v})$ tissue homogenates in Homogenization Buffer. Tissue homogenates were centrifuged at $1200 \mathrm{x}$ g for $10 \mathrm{~min}$. To optimize for AMPKK activity, polyethylene glycol (PEG 6000, Calbiochem) precipitations were done at cuts of $6 \%$ and $10 \%(\mathrm{w} / \mathrm{v})$ as previously described (15). Homogenates were then frozen at $95^{\circ} \mathrm{C}$ until analysis. Both the $1200 \mathrm{x}$ g supernatant and the PEG precipitates were 
assayed for AMPKK activity. Activation of recombinant AMPK alpha- $1_{312}$ subunit was used to determine AMPKK activity of homogenates (12). The AMPK alpha- $1_{312}$ subunit was prepared as previously described (36). Activation of AMPK alpha- $1_{312}$ was determined by radiolabel incorporation into AMARA peptide from ATP $\gamma \mathrm{P}^{32}$. Tissue homogenates $(2 \mu \mathrm{l})$ were incubated $\left(30^{\circ} \mathrm{C}\right)$ with AMPK alpha- $1_{312}$ in storage buffer $(4$ $\mu \mathrm{l})$ and AMPKK Assay Buffer $(4 \mu \mathrm{l})$. Buffer formulations are described below. After 20 min., AMPK Assay Buffer was added (15 $\mu \mathrm{l})$ and the reaction proceeded for an additional 10 minutes. The reaction was then stopped by spotting the reaction mixture $(15 \mu 1)$ on P81 filter papers (Whatman, Tewksbury, MA). Filter papers were washed in $100 \mathrm{ml} 1 \%$ phosphoric acid ( $6 \times 5 \mathrm{~min})$, once with acetone, and then air dried. Filter papers were transferred to glass liquid scintillation vials with $3 \mathrm{mls}$ of Ecolite solution (ICN; Irvine, CA) and counted for $10 \mathrm{~min}$.

Activity measurements for both $\alpha_{1}$ - and $\alpha_{2}$-AMPK were performed on immunoprecipitates from the $1200 \mathrm{x} \mathrm{g}$ homogenate. Isoform-specific affinity-purified antibodies (Affinity Bioreagents, Golden, CO) against TSPPDSFLDDHHLTR for $\alpha_{1}$ and MDDSAMHIPPGLKPH for $\alpha_{2}$ were used for immunoprecipitation of AMPK. Immunoprecipitation and $\alpha_{1}$ - and $\alpha_{2}$-AMPK activity measurements were done using the method of Hardie et al (13). Our protocol varied in that immunoprecipitations were overnight and the AMPK activity assay was on immunoprecipitates resuspended in the buffer described previously (41).

AMPK alpha- $1_{312}$ Storage Buffer. $50 \mathrm{mM}$ Tris-HCl, $250 \mathrm{mM}$ Mannitol, $1 \mathrm{mM}$ EDTA, 1 mM EGTA, 1 mM DTT, 0.02\% Brij-35 (w/v), 10\% glycerol (w/v), pH 7.4. 
AMPKK Assay Buffer. $100 \mathrm{mM}$ Hepes, $200 \mathrm{mM} \mathrm{NaCl}, 20 \%$ glycerol (w/v), $2 \mathrm{mM}$ EDTA, $12.5 \mathrm{mM} \mathrm{MgCl} 2,0.5 \mathrm{mM}$ AMP, $0.5 \mathrm{mM}$ ATP, $2.0 \mathrm{mM}$ DTT, pH 7.0. AMPK Assay Buffer. $40 \mathrm{mM}$ HEPES, $80 \mathrm{mM} \mathrm{NaCl}, 8 \%$ glycerol (w/v), $0.8 \mathrm{mM}$ EDTA, $0.8 \mathrm{mM}$ DTT, $5 \mathrm{mM} \mathrm{MgCl} 2,0.2 \mathrm{mM}$ AMP, $0.2 \mathrm{mM}$ ATP, $0.33 \mathrm{mM}$ AMRA peptide, $0.133 \mu \mathrm{Ci} / \mu \mathrm{ATP} \gamma \mathrm{P}^{32}, \mathrm{pH}$ 7.0. (AMP, ATP, DTT, and ATP $\gamma \mathrm{P}^{32}$ were added just prior to use.)

Immunoblotting. Immunoblots were performed on the 1,200-g supernatant. LKB1 immunoblots were performed on both the 1,200-g supernatant and the PEG precipitate. Tissue homogenates were diluted in water and $4 \mathrm{x}$ Laemmli's buffer $(1: 2: 1)$ (24). Diluted homogenates ( $40 \mu \mathrm{l})$ were loaded into $50 \mu \mathrm{l}$ well, Tris- $\mathrm{HCl}$ Ready Gels (Bio-Rad, Hercules CA): $5 \%$ gels for ACC, and Phospho-ACC, 7.5\% gels for AMPK alpha-1 subunit, Phospho-AMPK, LKB1; 10\% gels for AMPK gamma-3. Homogenates were then separated by SDS-PAGE for 30-35 minutes.

Measurement of Acetyl-CoA Carboxylase Activity. For measurement of AcetylCoA Carboxylase (ACC) activity, frozen tissue was ground to powder at liquid nitrogen temperature and homogenized in a buffer consisting of $200 \mathrm{mM}$ mannitol, $50 \mathrm{mM} \mathrm{NaF}$, $10 \mathrm{mM}$ Tris, $1 \mathrm{mM}$ EDTA, $10 \mathrm{mM} \beta$-mercaptoethanol, and $5 \mathrm{mg} / \mathrm{L}$ aprotinin, leupeptin, and anti-trypsin (pH 7.5). ACC activity measurements were done on resuspended ammonium sulfate precipitates and activity was determined at a citrate concentration of $0.5 \mathrm{mM}$ using the method of Thampy et al (37) as previously described (41).

Measurement of lactate, phosphocreatine, ATP, creatine and glycogen. Frozen gastrocnemius muscles were ground to powder under liquid nitrogen using a ceramic mortar and pestle. Perchloric acid extracts were made from the frozen muscle powder 
(100 mg powder / $\mathrm{ml} 6 \%$ PCA) and used for analysis of lactate (11), phosphocreatine (18), and ATP (18). Glycogen was measured as previously described (29). Muscle pH was estimated using the method of Dudley et al (6).

Statistical analyses. Results are presented as means \pm SE. Statistical significance was determined by one-way ANOVA using Fisher's LSD comparison of data sets using the Number Cruncher Statistical Software (NCSS, Kaysville, UT). A probability value of 0.05 was used to determine statistical significance in all analyses. 


\section{RESULTS}

As illustrated in Figure 1, Citrate Synthase activity was significantly higher $(\mathrm{P}<$ 0.001) in gastrocnemius muscles from trained (T) animals than those from control animals. The increase in this mitochondrial enzyme confirms the efficacy of the training protocol.

LKB1 protein content increased significantly $(\mathrm{P}<0.05)$ in both as a result of training (Figure 2). This increase in LKB1 was seen in western blots of both the 1200-g homogenate and the PEG precipitates. AMPKK activity was determined in both the 1200-g supernatant of the crude homogenate and resuspended PEG precipitates from the homogenate by measuring the increase in activity of the truncated alpha subunit of AMPK. Even though LKB1 increased in response to endurance training, AMPKK activity in both the 1200 -g supernatant and the PEG precipitate was significantly $(\mathrm{P}<$ 0.05) lower in the muscles of trained animals than in control animals (Figure 3). AMPKK activity did not increase in response to electrical stimulation in either control or trained animals. In trained animals, stimulation of the gastrocnemius did not change the AMPKK activity in either the 1200-g supernatant or the PEG precipitate (Figure 3). In control animals, electrical stimulation at both $.4 / \mathrm{sec}$ and $1 / \mathrm{sec}$ resulted in significantly $(\mathrm{P}<0.05)$ reduced AMPKK activity (compared to rest) in the $1200-\mathrm{g}$ supernatant of control animals (Figure 3). In the PEG precipitate from control animals, AMPKK activity tended to be decreased after stimulation at $1 / \mathrm{sec}$, but the difference from rest was not significant ( $\underline{\text { Figure 3)}}$.

It should be noted that the increase in LKB1 protein content in PEG precipitates and the decrease in AMPKK activity in muscle homogenates from trained rats as 
compared to controls conflict with results from a previous study in our lab (36). In the previous study using red quadriceps muscle from trained and control rats, there was no difference in LKB1 protein content in PEG precipitates and no difference in AMPKK activity between trained and control rats (36). The crude muscle homogenate in the previous study did show increases in LKB1 protein. The homogenization buffer used in the present study had detergent concentration of $1 \%$ compared to $0.5 \%$ detergent in the previous study. The changes in extraction of LKB1 and AMPKK activity caused by this change in detergent concentration have interesting implications for future study of AMPKK complexes and localization.

The decrease of AMPKK activity in control rats and the stability of AMPKK activity in trained rats after electrical stimulation are especially notable because AMPK phosphorylation was significantly increased in the same muscle homogenates. Western blot analysis of the 1200-g supernatant for phospho-AMPK (at $\mathrm{Thr}^{172}$ ) showed a significant $(\mathrm{P}<0.05)$ increase in phosphorylation as a result of stimulation at both $.4 / \mathrm{sec}$ and $1 / \mathrm{sec}$; this increase was seen in both trained and control animals (Figure 4). Although phospho-AMPK tended to be lower in trained than control at a stimulation rate of $1 / \mathrm{sec}$, the difference was not significant $(\mathrm{P}<0.14)$. However, if just the two 1/sec groups ( $\mathrm{T}$ and $\mathrm{C})$ were compared to each other the difference was significant $(\mathrm{P}<$ 0.05). AMPK activity was determined on resuspended immunoprecipitates specific for $\mathrm{AMPK} \alpha_{1}$ and $\alpha_{2}$. The activity of both isoforms increased significantly $(\mathrm{P}<0.05)$ in response to electrical stimulation at $.4 / \mathrm{sec}$ and $1 / \mathrm{sec}$ (Figure 5). There were no significant differences between trained and control rats in AMPK $\alpha_{1}$ or $\alpha_{2}$ activity at any stimulation rate. 
Acetyl-CoA Carboxylase (ACC) activity decreased significantly $(\mathrm{P}<0.05)$ in muscles from both trained and control rats as a result of electrical stimulation at both $.4 / \mathrm{sec}$ and $1 / \mathrm{sec}$ stimulation frequencies (Figure 6 ). ACC activity was not significantly different between trained and control rats at any stimulation rate. This decrease in ACC activity correlated with the increase in phosphorylation of ACC (by AMPK). Western blots for phospho-ACC showed significant increases $(\mathrm{P}<0.05)$ in phosphorylation at both stimulation rates in trained and control rats (igure 6). When compared to control rats, trained rats had significantly more phospho-ACC at rest and when stimulated at $.4 / \mathrm{sec}$ but not at $1 / \mathrm{sec}$ (Figure 6$)$.

Phosphocreatine $(\mathrm{PCr})$ concentration decreased significantly $(\mathrm{P}<0.05)$ in stimulated gastrocnemius muscle of trained and control animals at both $.4 / \mathrm{sec}$ and $1 / \mathrm{sec}$ stimulation rates (Figure 7). At a stimulation rate of $1 / \mathrm{sec}, \mathrm{PCr}$ in muscles from control rats tended to be lower than trained but the difference was not significant. However, if just the two 1/sec groups ( $\mathrm{T}$ and $\mathrm{C}$ ) were compared to each other the $\mathrm{PCr}$ was significantly lower in control rats $(\mathrm{P}<0.05)$. Glycogen concentration was significantly higher in muscles from trained rats at rest and after electrical stimulation (Figure 7). Trained animals were also more resistant to glycogen depletion; glycogen was significantly depleted from rest only after stimulation at $1 / \mathrm{sec}$. In control animals, glycogen concentration decreased significantly at both stimulation rates $(\mathrm{P}<0.05)$.

Lactic acid increased significantly $(\mathrm{P}<0.05)$ in muscles of both trained and control animals as a result of electrical stimulation (Figure 8). At a stimulation rate of $1 / \mathrm{sec}$ lactate was significantly lower in muscles of trained animals. The concentration of ATP decreased significantly $(\mathrm{P}<0.05)$ in both trained and control rats at the $1 / \mathrm{sec}$ 
stimulation rate; there were no significant differences in ATP concentration between trained and controls at rest or after electrical stimulation (Figure 8). 


\section{DISCUSSION}

This study reaffirms previous findings of increased activity and phosphorylation of AMPK in response to muscle contraction $(7,25,26,28)$. This increase in phosphoAMPK suggests increased phosphorylation by the upstream kinase. In this study, we hypothesized that AMPKK activity would be increased in muscle extracts from electrically stimulated gastrocnemius muscle and that the increases in both AMPK and AMPKK activities would be attenuated in endurance-trained animals as compared to controls.

Several studies have noted that phosphorylation and activation of skeletal muscle AMPK in response to muscle contraction is decreased after endurance-training $(7,25)$. In this study, AMPK signaling was not attenuated in electrically-stimulated muscles of trained rats as compared to control rats. AMPK activity and phosphoAMPK tended to be lower in muscle extracts from trained rats, but the differences failed to reach significance. P-ACC was significantly lower at rest and a stimulation rate of $.4 / \mathrm{sec}$ but not at $1 / \mathrm{sec}$ (the rate where the most attenuation would be expected). However, ACC activity was not significantly different between trained and control rats at any stimulation frequency. Overall, no consistent evidence for blunting of AMPK responses was seen in trained animals. One possible explanation for this is that rat gastrocnemius muscles contain both IIA and IIB fibers. Type IIB fibers have lower levels of mitochondrial enzymes and this may dilute the effects of training we would expect to see in pure II A fibers.

There are several mechanisms by which AMPKK phosphorylation of AMPK could be enhanced in response to muscle contraction. One possibility is covalent 
modification of AMPKK through phosphorylation or dephosphorylation by upstream kinases or phosphatases as a result of muscle contraction. It is also possible that contraction causes either association or disassociation of proteins that alter the AMPKK activity. A third possibility is direct allosteric activation or disinhibition of AMPKK by molecules or ions that are produced or degraded during contraction (PCr, AMP, $\mathrm{H}+$, glycogen, etc). A fourth option is that AMPKK may be sequestered to a different cellular location in response to muscle contraction (cytosolic vs. nuclear, membranous, or vesicular).

Lastly, it may be that AMPKK is constitutively in its active form and that the increase in AMPK phosphorylation is solely due to substrate effects. Allosteric modulators of AMPK (such as AMP, PCr, and glycogen) may increase exposure of Thr172 for phosphorylation by AMPKK. Additionally, contraction may result in reduced activity of protein phosphatases which dephosphorylate AMPK resulting in lasting phosphorylation of AMPK. It is most likely that several of the above mechanisms work in concert to increase the amount of phospho-AMPK in response to muscle contraction.

We measured AMPKK activity in both PEG precipitates and crude homogenates of electrically-stimulated rat muscle by measuring in vitro activation of the truncated AMPK $\alpha$ subunit. AMPKK activity did not increase as a result of electrical stimulation in gastrocnemius muscle of either control or trained rats, but phospho-AMPK did increase in response to stimulation. In fact, AMPKK activity significantly decreased in the 1200-g homogenates of control rats; this same trend was seen in the PEG precipitate but it did not reach significance. Sakamoto et al found also found that in situ 
contraction of rat skeletal muscle (untrained) increased phospho-AMPK and AMPK activity the activity of LKB1 (AMPKK) did not increase (30). If AMPKK were activated covalently in response to muscle contraction we would expect the activation to be stable enough for measurement in the muscle extracts. In addition, the homogenization buffer used to process the muscles contained phosphatase inhibitors to prevent dephosphorylation of proteins during tissue processing; this same processing method successfully preserves AMPK activation as a result of phosphorylation. This evidence suggests that AMPKK is not activated by phosphorylation/dephosphorylation or some other covalent modification as a result of muscle contraction. The increase in phosphorylation of AMPK as a result of muscle contraction must be due to some other mechanism, such as those discussed previously.

Interestingly, Chen et al did see an increase in AMPKK activity in human muscle after higher work-load exercise bouts (3). After exercise for 20 minutes at 59 and $79 \%$ of VO2 max, AMPKK activity was increased approximately $50 \%$ (3). This apparent discrepancy from our results may indicate species-specific regulation of AMPKK in response to muscle contraction.

LKB1 in complex with MO25 and STRAD has been identified as a major upstream kinase in the AMPK cascade in liver $(14,27,32,44)$. A recent study in our lab used muscle-specific (heart and skeletal) LKB1 knock-out mice to study the role of LKB1 in the AMPK kinase cascade in skeletal muscle (38). In that study, electrical stimulation of muscle increased phospho-AMPK and AMPK activity in wild type mice but LKB1 knockout mice did not show similar increases. In addition, muscles isolated from LKB1 knockout mice at rest had lower phospho-AMPK and phospho-ACC than 
their wild-type counterparts (38). This report confirmed the results of other LKB1 knock-out studies. Sakamoto et al also reported the muscle-specific LKB1 knockouts had greatly reduced basal AMPK $\alpha 2$ activity and that this activity was not increased in response to AICAR, phenformin, or muscle contraction - all of which are wellestablished activators of AMPK (31). AICAR and contraction-induced glucose uptake was also diminished in LKB1 knockouts $(22,31)$. These and other studies provide convincing evidence that LKB1 is a part of the major upstream kinase in the AMPK signaling pathway in skeletal muscle.

In the current study, LKB1 protein content was significantly increased in response to training; this increase was $\sim 2$-fold in 1200-g homogenates of gastrocnemius muscle. This finding is especially interesting since AMPKK activity was significantly lower in muscle extracts from trained rats as compared to controls; in PEG precipitates activity decreased $73 \%$ in response to endurance training. Since LKB1 has been identified as a major AMPKK in skeletal muscle, we would expect increases in LKB1 protein to correspond to increased AMPKK activity. In another study in our lab, endurance training significantly increased LKB1 and MO25 protein content in red quadriceps but also did not increase AMPKK activity (36). STRAD mRNA did not increase in response to training; STRAD protein levels could not be evaluated. Since STRAD is necessary for the kinase activity of LKB1/MO5/STRAD complexes $(14,15)$ decreased expression or increased degradation of STRAD protein as a result of training could result in decreased AMPKK activity. More research on the effect of endurancetraining on STRAD is necessary to determine the plausibility of this hypothesis. 
In this study LKB1 protein was significantly increased in both the $1200-\mathrm{g}$ homogenate and the PEG precipitates. Also, AMPKK activity was decreased in trained rats compared to controls. In a previous study in our lab using red quadriceps muscle from trained and control rats, there was no difference in LKB1 protein content in PEG precipitates and no difference in AMPKK activity between trained and control rats (36). Homogenates in the previous study were centrifuged at $700 \mathrm{xg}$ while the current study used a $1200 \mathrm{x}$ g centrifugation. The homogenization buffer used in the present study had detergent concentration of $1 \%$ compared to $0.5 \%$ detergent in the previous study. Changes in detected LKB1 protein content and AMPKK activity as a result of a change in detergent concentration or centrifugation speed may indicate differential regulation of AMPKK resulting from alterations in protein complexing/binding partners or changes in cellular localization.

There is some evidence that much of the increased AMPKK phosphorylation of AMPK as a result of energy challenges may be due to substrate effects. For example, AMP is a major activator of the cascade and has been shown to activate AMPK via 3 distinct mechanisms: direct allosteric activation of kinase activity, allosterically making it a better substrate for AMPKK phosphorylation, and inhibiting dephosphorylation of Thr172 by protein phosphatases $(5,15,16,20)$. While early reports indicated AMP may also directly activate AMPKK $(15,16)$ this does not appear to be the case $(21)$. In addition, a recent study showed that phenformin and AICAR treatment of skeletal muscle increased AMPK phosphorylation and activity but did not increase LKB1 (AMPKK) activity indicating effects at the substrate level (30). 
In summary, LKB1 protein content increased in gastrocnemius muscle as a result of endurance training but AMPKK activity decreased. The functional significance of increased LKB1 protein is unknown. Electrical stimulation of gastrocnemius muscle increased phosphorylation and activity of AMPK but did not increase AMPKK activity in trained or control rats. These data suggest that contraction-induced activation of AMPKK is not a result of covalent modification. Activation may result from direct allosteric enhancement, changes in protein associations, or various enhancements of AMPK as a substrate for a constitutivelyactive AMPKK. In addition, it is possible that the blunted phosphorylation and activation of AMPK seen in other studies of trained animals may be a result of significantly reduced AMPKK activity. 


\section{REFERENCES}

\section{Boudeau J, Scott JW, Resta N, Deak M, Kieloch A, Komander D, Hardie}

DG, Prescott AR, van Aalten DM, and Alessi DR. Analysis of the LKB1-STRADMO25 complex. J Cell Sci 117: 6365-6375, 2004.

2. Carling D, Clarke PR, Zammit VA, Hardie DG. Purification and characterization of the AMP-activated protein kinase. Copurification of acetyl-CoA carboxylase and 3-hydroxy-3-methylglutaryl-CoA reductase kinase activities. Eur J Biochem, 186: 129-36, 1989.

\section{Chen ZP, Stephens TJ, Murthy S, Canny BJ, Hargreaves M, Witters LA,} Kemp BE, and McConell GK. Effect of exercise intensity on skeletal muscle AMPK signaling in humans. Diabetes 52: 2205-2212, 2003.

4. Cheung PCF, Salt IP, Davies SP, Hardie DG, Carling D. Characterization of AMP-activated protein kinase $\gamma$-subunit isoforms and their role in AMP binding. Biochem J 346: 659-669, 2000.

5. Davies SP, Helps NR, Cohen PTW, Hardie DG. 5'-AMP inhibits dephosphorylation, as well as promoting phosphorylation, of the AMP-activated protein kinase. Studies using bacterially expressed human protein phosphatase-2C $\alpha$ and native bovine protein phosphatase-2A . FEBS Letters, 377: 421-425, 1995.

6. Dudley GA, Terjung RL. Influence of acidosis on AMP deaminase activity in contracting fast-twitch muscle. Am J Physiol 248: C43-C50, 1985.

7. Durante PE, Mustard KJ, Park SH, Winder WW, Hardie DG. Effects of endurance training on activity and expression of AMP-activated protein kinase isoforms in rat muscle. Am J Physiol Endocrinol Metab, 283: E178-E186, 2002. 
8. Durante PE, Mustard KJ, Park SH, Winder WW, Hardie DG. Effects of endurance training on activity and expression of AMP-activated protein kinase isoforms in rat muscles. Am J Physiol Endocrinol Metab 283: E178-E186, 2002.

9. Dyck JRB, Guang G, Widmer J, Stapleton D, Fernandez CS, Kemps BE, and Witters LA. Regulation of 5'-AMP-activated protein kinase activity by the noncatalytic $\beta$ and $\gamma$ subunits. J Biol Chem 271: 17798-17803, 1996.

10. Garton AJ, Campbell DG, Carling D, Hardie DG, Colbran RJ, Yeaman SJ. Phosphorylation of bovine hormone-sensitive lipase by the AMP-activated protein kinase. A possible antilipolytic mechanism. Eur J Biochem 179: 249-54, 1989.

11. Gutmann I and Wahlefeld AW. L-(+)-Lactate: determination with lactate dehydrogenase and NAD. In: Methods of Enzymatic Analysis, edited by Bergemeyer HU. New York: Academic, 1974, p. 1464-1468.

12. Hamilton SR, O’Donnell JB Jr., Hammett A, Stapleton D, Habinowski SA, Means AR, Kemp BE, and Witters LA. AMP-activated protein kinase kinase: detection with recombinant AMPK alphal subunit. Biochem Biophys Res Commun 293: 892-898, 2002.

13. Hardie DG, Salt IP, and Davies SP. Analysis of the role of the AMP-activated protein kinase in the response to cellular stress. In: Methods in Molecular Biology, edited by Keyse SM. Totowa, NJ: Humana, 2000, p. 63-74.

\section{Hawley SA, Boudeau J, Reid JL, Mustard KJ, Udd L, Makela TP, Alessi}

DR, and Hardie DG. Complexes between the LKB1 tumor suppressor, STRAD alpha/beta and MO25 alpha/beta are upstream kinases in the AMP-activated protein kinase cascade. J Biol 2: 28, 2003. 


\section{Hawley SA, Davison M, Woods A, Davies SP, Beri RK, Carling D, and}

Hardie DG. Characterization of the AMP-activated protein kinase kinase from rat liver and identification of threonine 172 as the major site at which it phosphorylates AMP-activated protein kinase. J Biol Chem 271: 27879-27887, 1996.

\section{Hawley SA, Selbert MA, Goldstein EG, Edelman AM, Carling D, Hardie}

DG. 5'AMP activates the AMP-activated protein kinase cascade, and $\mathrm{Ca} 2+/$ calmodulin activates the calmodulin-dependent protein kinase I cascade, via three independent mechanisms. J Biol Chem 270 (45):27186-91, 1995.

\section{Hayashi T, Hirshman MF, Kurth EJ, Winder WW, and Goodyear LJ.}

Evidence for the 5' AMP-activated protein kinase mediation of the effect of muscle contraction on glucose transport. Diabetes 47: 1369-1373, 1998.

18. Heinz F and Weisser H. Creatine phosphate. In: Methods of Enzymatic Analysis, edited by Bergemeyer HU. New York: Academic, 1983, p. 507-514.

\section{Horman S, Browne G, Krause U, Patel J, Bertommen D, Bertrand L,} Lavoinne A, Hue L, Proud C, Rider M. Acivation of AMP-activated protein kinase leads to the phosphorylation of elongation factor 2 and inhibition of protein synthesis. Curr Biol 12: 1419-1423, 2002.

20. Kahn BB, Alquier T, Carling D, Hardie DG. AMP-activated protein kinase: Ancient energy gauge provides clues to modern understanding of metabolism. Cell Metab 1: 15-25, 2005.

\section{Kemp BE, Stapleton D, Campbell DJ, Chen ZP, Murthy S, Walter M,} Gupta A, Adams JJ, Katsis F, van Denderen B, Jennings IG, Iseli T, Michell BJ, 
and Witters LA. AMP-activated protein kinase, super metabolic regulator. Biochem Soc Trans 31: 162-168, 2003.

22. Koh H-J, Hirshman MF, Peter LE, Li T, Fujii N, Goodyear LJ. LKB1 regulates contraction-stimulated glucose transport in mouse skeletal muscle. FASEB $J$ 21: 895.16, 2007.

23. Kurth-Kraczek EJ, Hirshman MF, Goodyear LJ, Winder WW. 5'-AMPActivated Protein Kinase Activation Causes GLUT4 Translocation in Skeletal Muscle. Diabetes 48: 1667-1671, 1999.

24. Laemmli UK. Cleavage of structural proteins during the assembly of the head of bacteriophage T4. Nature 227: 680-685, 1970.

25. Nielsen JN, Mustard DJW, Graham DA, Yu H, MacDonald CS, Pilegaard H, Goodyear LJ, Hardie DG, Richter EA, Wojtaszewski, JFP. 5'-AMP-activated protein kinase activity and subunit expression in exercise-trained human skeletal muscle. J Appl Physiol 94: 631-641, 2003.

26. Nielsen JN, Mustard KJ, Graham DA, Yu H, MacDonald CS, Pilegaard H, Goodyear LJ, Hardie DG, Richter EA, and Wojtaszewski JF. 5'-AMP-activated protein kinase activity and subunit expression in exercise-trained human skeletal muscle. J Appl Physiol 94: 631-641, 2003.

\section{Park H, Daushik VK, Constant S, Prentki M, Przybytkowski E, Ruderman} NB, Saha AK. Coordinate regulation of malonyl-CoA decarboxylase, sn-glycerol-3phosphate acyltransferase, and acetyl-CoA decarboxylase, by AMP-activated protein kinase in rat tissues in response to exercise. J Biol Chem 277: 32571-32577, 2002. 
28. Park SH, Gammon SR, Knippers JD, Paulsen SR, Rubink DS, and Winder WW. Phosphorylation-activity relationships of AMPK and acetyl-CoA carboxylase in muscle. J Appl Physiol 92: 2475-2482, 2002.

29. Passonneau JV and Lowry OH. Enzymatic Analysis: A Practical Guide. Totowa, NJ: Humana, 1993, p. 177-178.

30. Sakamoto K, Goransson O, Hardie DG, Alessi DR. Activity of LKB1 and AMPK-related kinases in skeletal muscle: effects of contraction, phenformin, and AICAR. Am J Physiol Endocrinol Metab 287: E310-E317, 2004.

31. Sakamoto K, McCarthy A, Smith D, Green KA, Hardie DG, Ashworth A, Alessi DR. Deficiency of LKB1 in skeletal muscle prevents AMPK activation and glucose uptake during contraction. EMBO J 24: 1810-20, 2005.

32. Shaw RJ, Kosmatka M, Bardeesy N, Hurley RL, Witters LA, DePinho RA, and Cantley LC. The tumor suppressor LKB1 kinase directly activates AMPactivated kinase and regulates apoptosis in response to energy stress. Proc Natl Acad Sci U S A 101: 3329-3335, 2004.

33. Srere PA. Citrate Synthase. Methods Enzymol. 13: 3-6, 1969.

34. Stapelton D, Mitchelhill KI, Gao G, Widmer J, Michell BJ, The T, House CM, Fernandez CS, Cox T, Witters LA, Kemp BE. Mammalian AMP-activated Protein Kinase Subfamily. J Biol Chem 271(2): 611-614, 1996.

35. Stein SC, Woods A, Jones NA, Davison MD, Carling D. The regulation of AMP-activated protein kinase by phosphorylation. Biochem J, 345: 437-43, 2000.

36. Taylor EB, Hurst D, Greenwood LJ, Lamb JD, Cline TD, Sudweeks SN, and Winder WW. Endurance training increases LKB1 and MO25 protein but not 
AMP-activated protein kinase kinase activity in skeletal muscle. Am J Physiol Endocrinol Metab. 287: E1082-E1089, 2004.

37. Thampy KG, Wakil SJ. Activation of Acetyl-CoA carboxylase. J Biol Chem 260: 6318-6323, 1985.

\section{Thomson DM, Porter BB, Tall JH, Kim H-J, Barrow JR, and Winder WW.}

Skeletal muscle and heart LKB1 deficiency causes decreased voluntary running and reduced muscle mitochondrial marker enzyme expression in mice. Am J Physiol Endocrinol Metab 292: E196-E202, 2007.

39. Watt MJ, Steinberg GR, Chan S, Garnham A, Kemp BE, Febbraio MA. Beta-adrenergic stimulation of skeletal muscle HSL can be overridden by AMPK signaling. FASEB J 18: 1445-6, 2004.

40. Winder WW and Hardie DG. AMP-activated protein kinase, a metabolic master switch: possible roles in Type 2 diabetes. Am J Physiol Endocrinol Metab 277: E1-10, 1999.

41. Winder WW and Hardie DG. Inactivation of acetyl-CoA carboxylase and activation of AMP-activated protein kinase in muscle during exercise. Am J Physiol Endocrinol Metab 270: E299-E304, 1996.

42. Winder WW. Energy-sensing and signaling by AMP-activated protein kinase in skeletal muscle. J Appl Physiol, 91: 1017-1028, 2001.

43. Woods A, Bertommens D, Neumann D, Turk R, Bayliss J, Schlattner U, Wallimann T, Carling D, Rider MH. Identification of phosphorylation sites in AMP-activated protein kinase (AMPK) for upstream kinases and study of their roles by site-directed mutagenesis. J Biol Chem, 278(31): 28434-442, 2003. 
44. Woods A, Johnstone SR, Dickerson K, Leiper FC, Fryer LG, Neumann D, Schlattner U, Wallimann T, Carlson M, and Carling D. LKB1 is the upstream kinase in the AMP-activated protein kinase cascade. Curr Biol 13: 2004-2008, 2003. 45. Yang W, Hong YH, Shen XG, Fankowski C, Camp HS, Leff T. Regulation of transcription by AMP-activated protein kinase: phosphorylation of p300 blocks its interaction with nuclear receptors. J Biol Chem 276: 38341-4, 2001. 


\section{FIGURE LEGENDS}

Figure 1. Citrate Synthase activity in gastrocnemius muscle of control and trained rats. Values are means \pm SEM, $n=7$. ${ }^{*}$ Significantly different from control rats, $\mathrm{P}<0.001$.

Figure 2. LKB1 immunoblots in gastrocnemius muscle of control (C) and trained (T) rats. Values are means $\pm \mathrm{SEM}, n=9$. ${ }^{*}$ Significantly different from control, $\mathrm{P}<0.05$.

Figure 3. AMP-activated protein kinase kinase (AMPKK) activity in resting and electrically stimulated gastrocnemius muscle from control and trained rats. Top: AMPKK activity in the 1200-g supernatant. Bottom: AMPKK activity in resuspended PEG precipitates. Values are means \pm SEM,$n=7-9 . *$ Significantly different from control at the same stimulation rate, $\mathrm{P}<0.05$. $†$ Significantly different from Rest in control animals, $\mathrm{P}<0.05$.

Figure 4. Phospho-AMPK (at $\mathrm{Thr}^{172}$ ) immunoblots in resting and electrically stimulated gastrocnemius muscles from control and trained rats. Values are means \pm SEM, $n=9$. *Significantly different from rest, $\mathrm{P}<0.05$.

Figure 5. Activity of $\alpha_{1}$ and $\alpha_{2}$ isoforms of AMP-activated protein kinase (AMPK) in resting and stimulated gastrocnemius muscles from control and trained rats. Values are means \pm SEM, $n=9 . *$ Significantly different from Rest, $\mathrm{P}<0.05$.

Figure 6. Top: Phospho-acetyl-CoA carboxylase (P-ACC) immunoblot quantification in resting and stimulated gastrocnemius muscle from control and trained rats. Values are means $\pm \mathrm{SEM}, n=10$. Bottom: ACC activity in resting and stimulated gastrocnemius muscle from control and trained rats. Values are means $\pm \operatorname{SEM}, n=9$. *Significantly different from Rest, $\mathrm{P}<0.05$. †Significantly different from control at same stimulation rate. 
Figure 7. Phosphocreatine (PCr) and Glycogen concentrations in resting and stimulated gastrocnemius muscle from control and trained rats. Values are means \pm SEM, $n=9$. *Significantly different from Rest, $\mathrm{P}<0.05$. $†$ Significantly different from control at same stimulation rate, $\mathrm{P}<0.05$.

Figure 8. ATP and Lactate concentrations in resting and stimulated gastrocnemius muscle from control and trained rats. Values are means \pm SEM, $n=9$. *Significantly different from Rest, $\mathrm{P}<0.05$. † Significantly different from control at same stimulation rate, $\mathrm{P}<0.05$. 


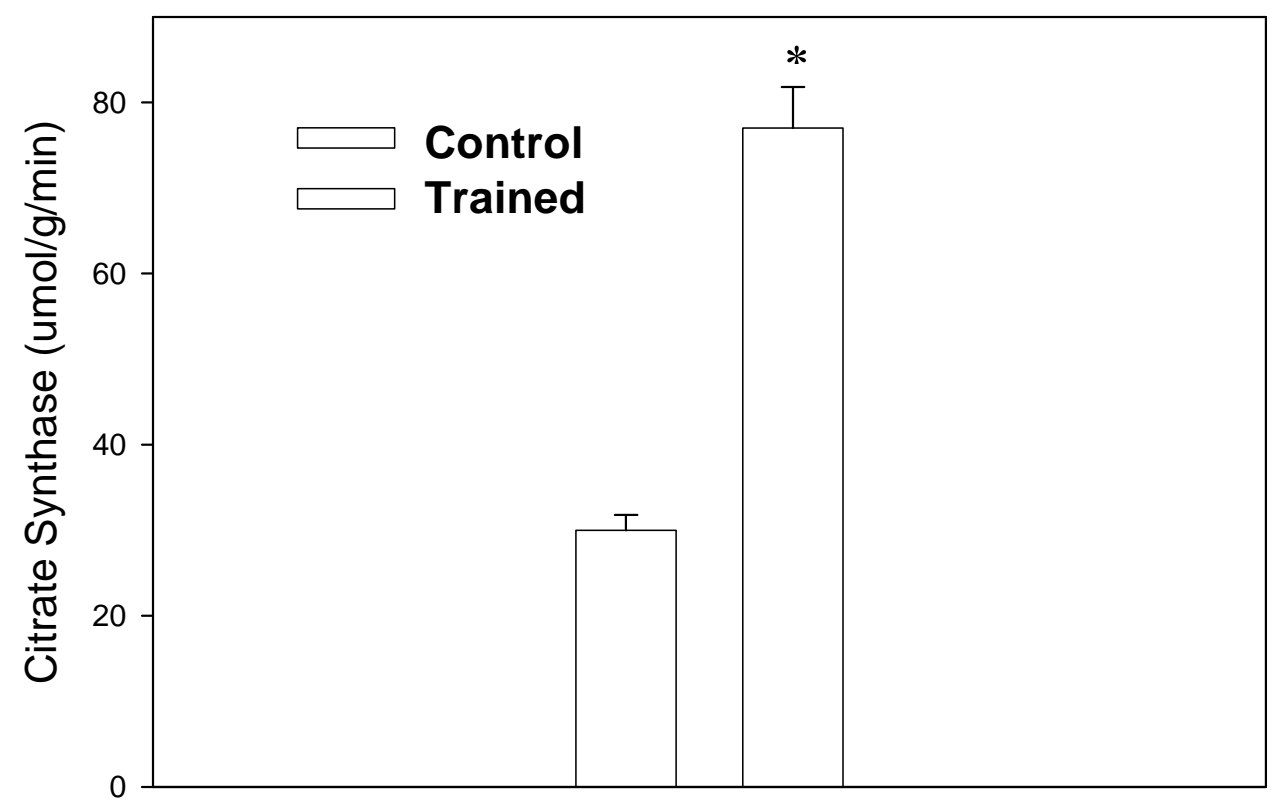

Figure 1. Citrate Synthase Activity 
$\begin{array}{llllll}\mathbf{C} & \mathbf{T} & \mathbf{C} & \mathrm{T} & \mathbf{C} & \mathbf{T}\end{array}$

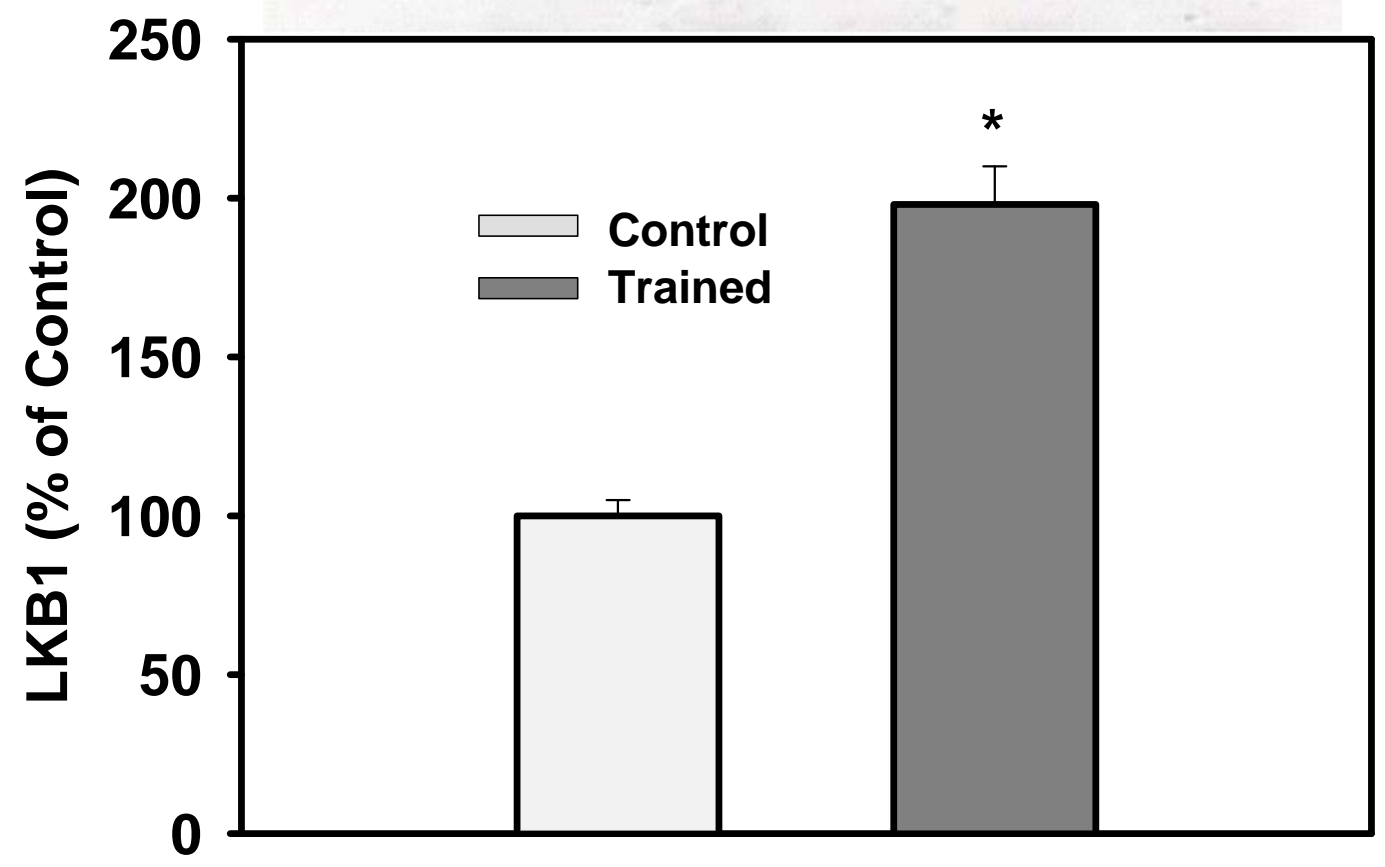

Figure 2. LKB1 Protein Content 

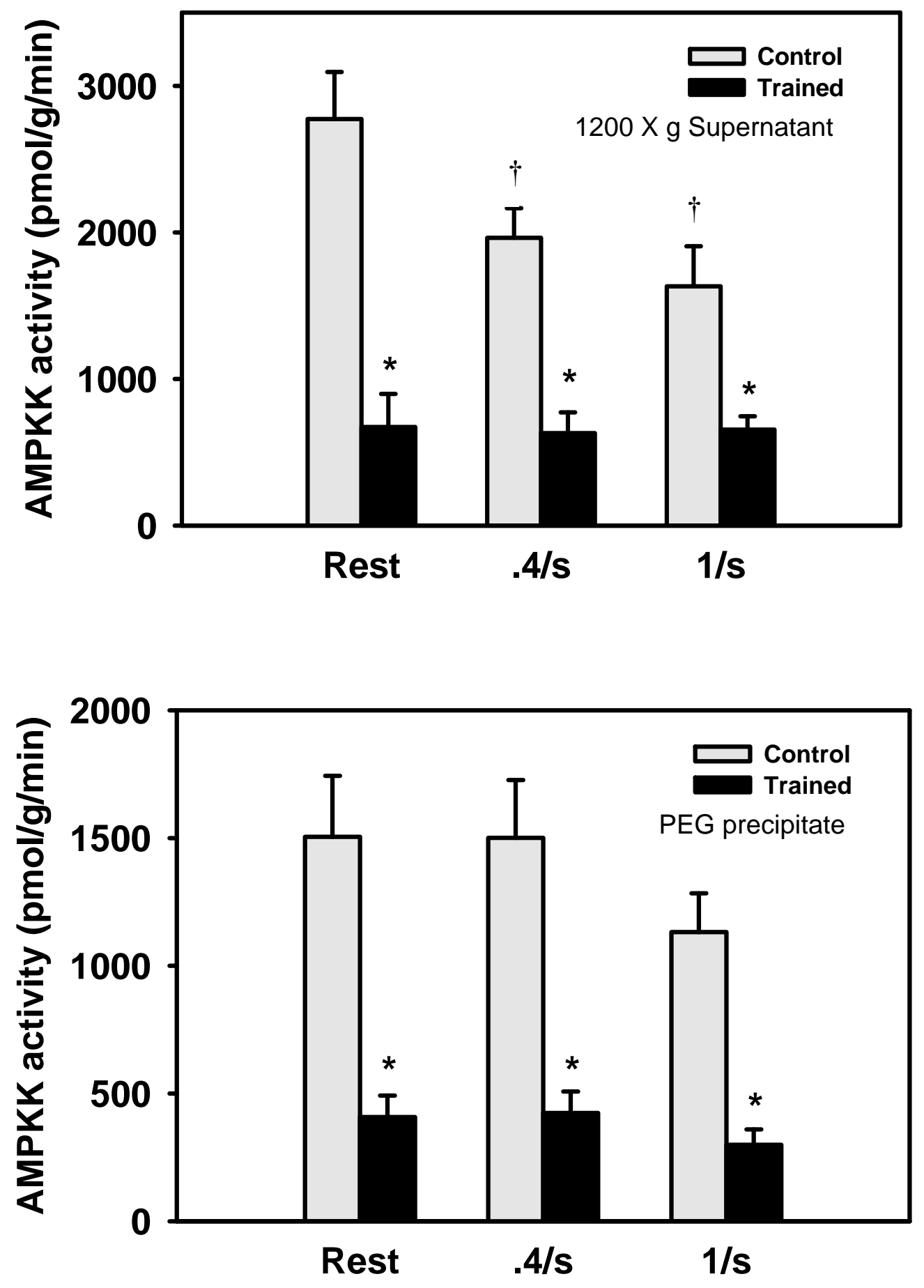

Figure 3. AMPKK Activity 


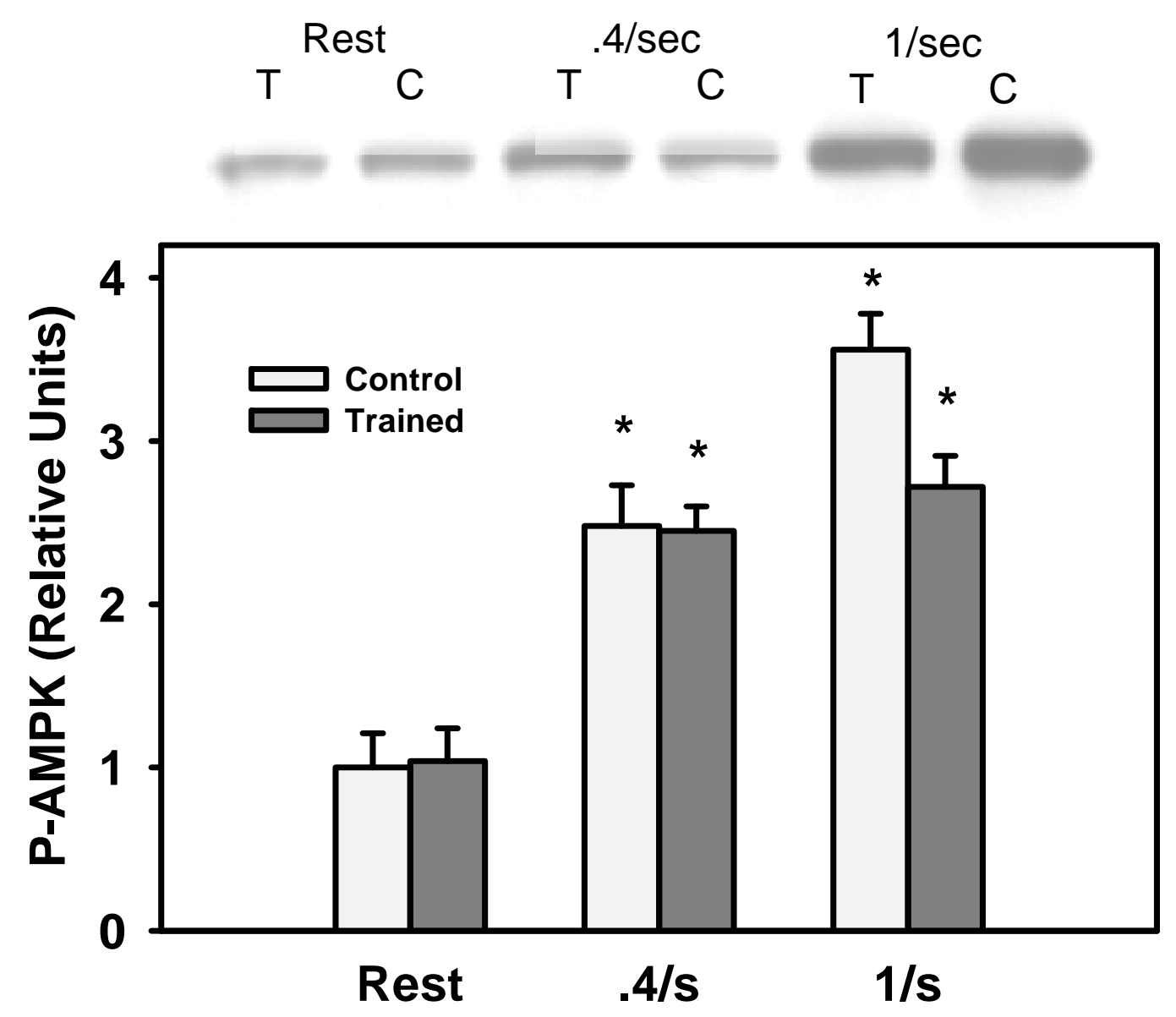

Figure 4. AMPK Phosphorylation 

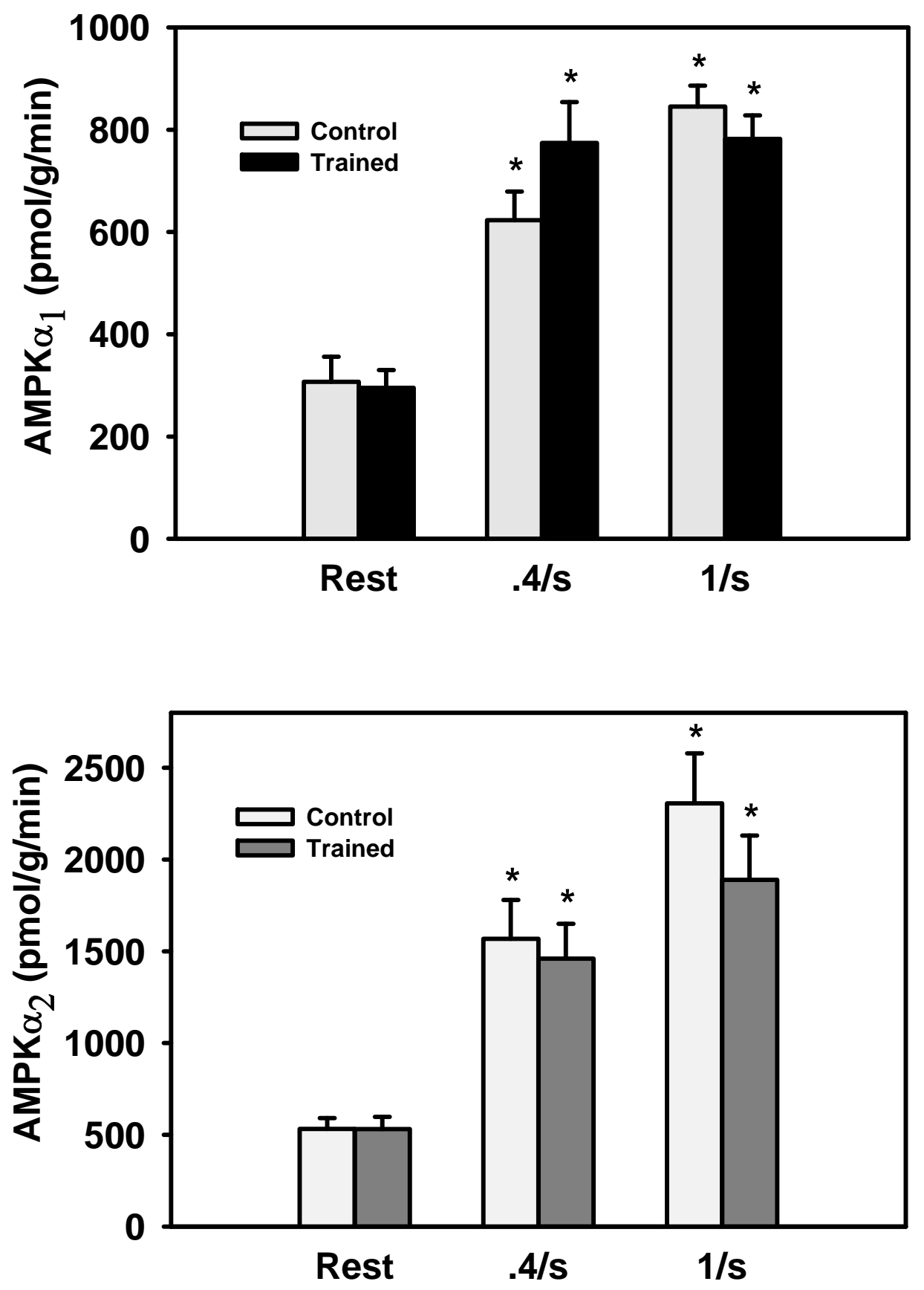

Figure 5. $A M P K \alpha_{1}$ and $A M P K \alpha_{2}$ Activity 

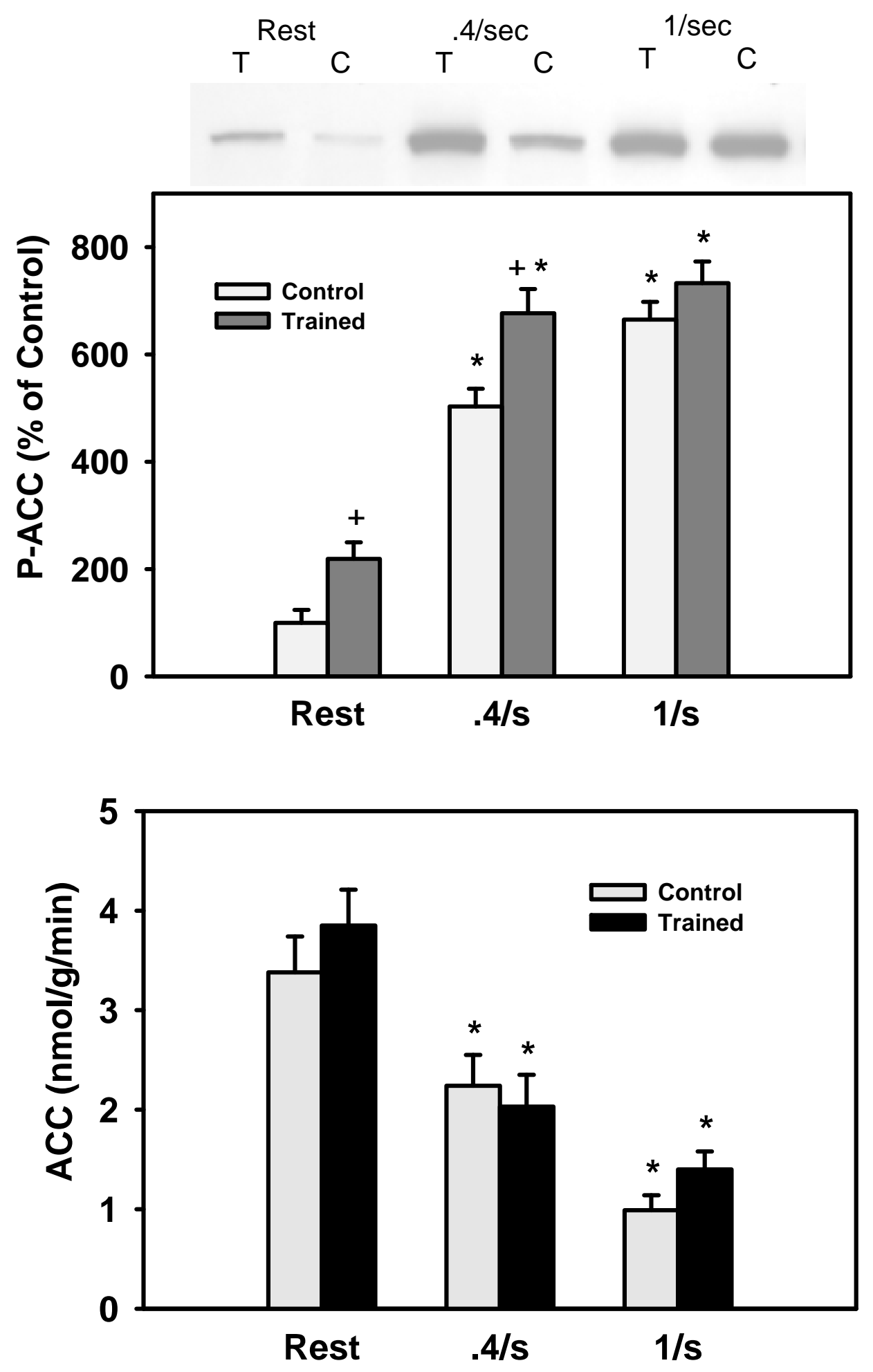

Figure 6. Acetyl-CoA Carboxylase (ACC) Activity and Phosphorylation 

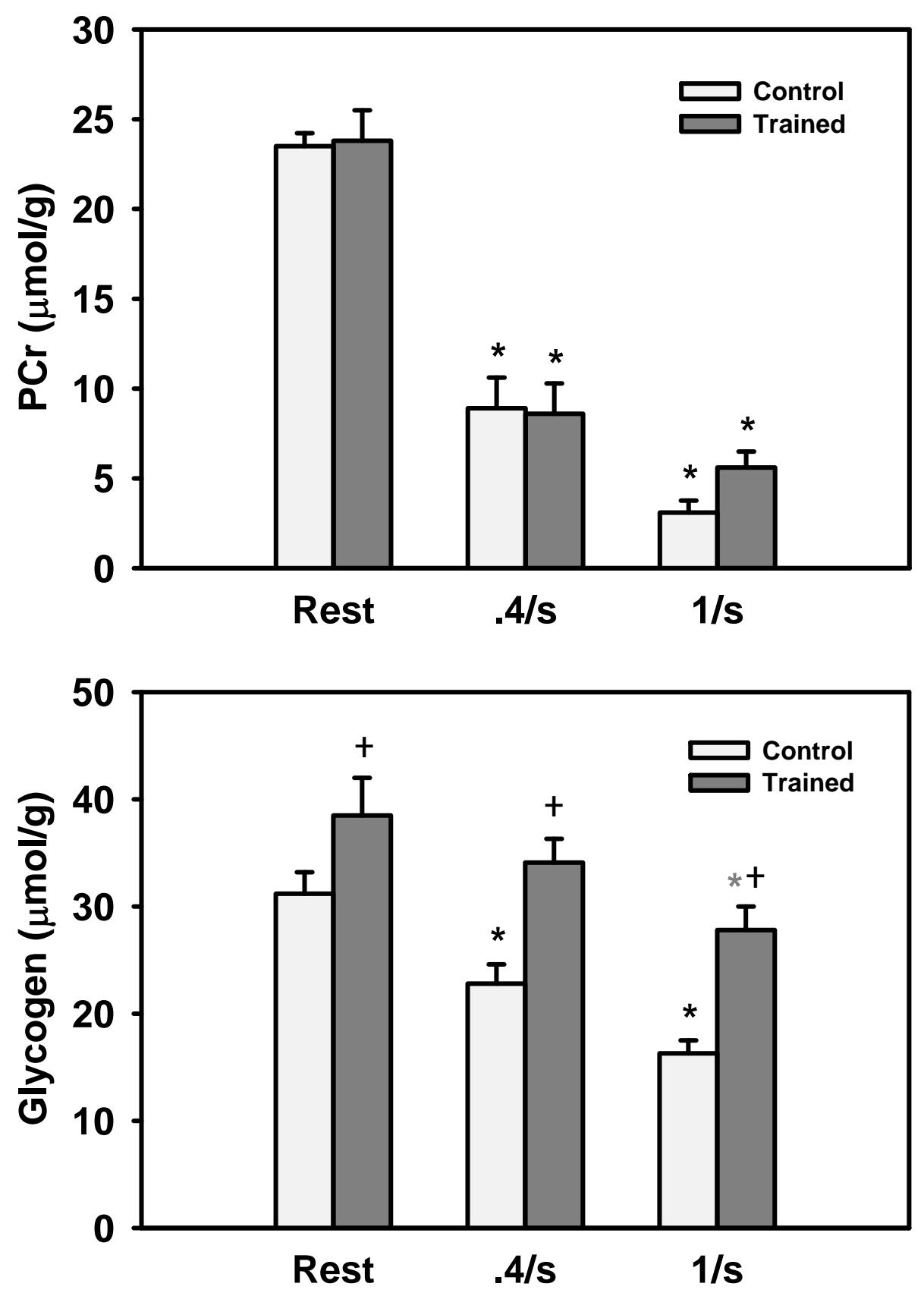

Figure 7. Phosphocreatine (PCr) and Glycogen Concentrations 

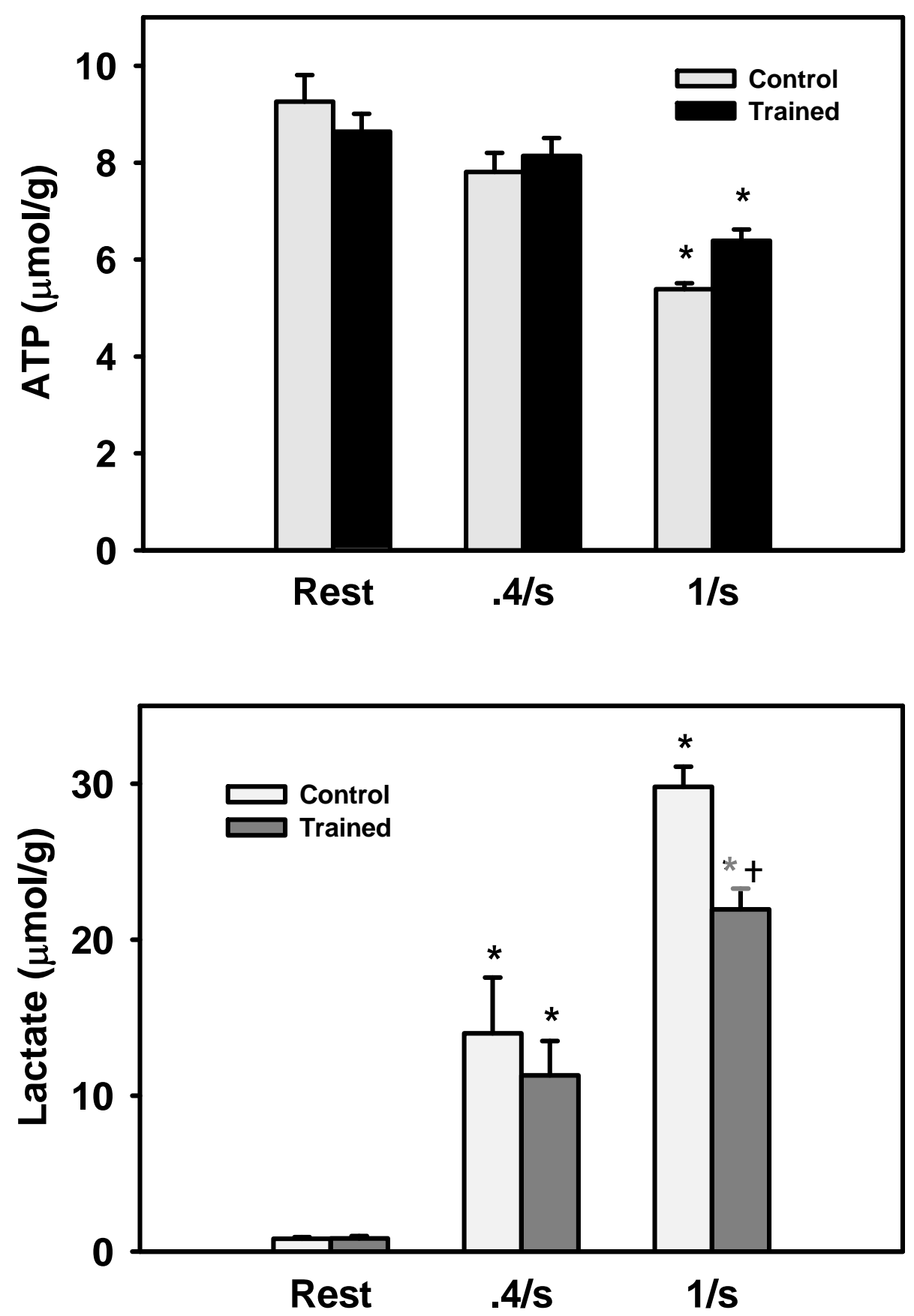

Figure 8. ATP and Lactate Concentrations 


\title{
Curriculum Vitae
}

\section{Denise Hurst}

\author{
H \& I Lab, University of Utah, SOM \\ 30N. 1900E. Rm AR121 \\ SLC UT 84132-1904 \\ Denisely1@gmail.com
}

\section{Education}

MS. Physiology \& Developmental Biology, Brigham Young University, August 2007. Thesis: AMP-Activated Protein Kinase Kinase Activity and Phosphorylation of AMPActivated Protein Kinase in Contracting Muscle of Sedentary and Endurance Trained Rats

BS. Neuroscience, Chemistry Minor, Brigham Young University, August 2002.

ASSC. Pre-Medicine, Snow College, May 2001.

\section{Experience}

HLA Technologist, Histocompatibility and Immunogenetics Laboratory, University of Utah Hospitals \& Clinics, 2004 to present.

Graduate Laboratory Research, Laboratory of Dr. William W. Winder, Brigham Young University, 2003-04.

Teaching Assistant, Human Physiology (Zoology 460), Brigham Young University, Fall 2002.

Teaching Assistant, Molecular Biology (Zoology 371), Brigham Young University, Winter 2002.

\section{Publications}

Virtual crossmatch improves organ allocation in sensitized patients. Islam N, Stehlik J, Hurst D, Movesian MA, Reddy BT, Gilbert EM, Kfoury AG, Renlund DG, Bader FM, Bull DA, Fuller A, Hammond MEH, Eckels D, Journal of Heart and Lung Transplantation. J Heart Lung Transplant Feb 26 (2S), S189, 2007.

AMP-Activated Protein Kinase Kinase Activity and Phosphorylation of AMP-Activated Protein Kinase in Contracting Muscle of Sedentary and Endurance Trained Rats. Hurst D, Taylor EB, Cline TD, Greenwood LJ, Compton CL, Lamb JD, and Winder WW. Am J Physiol Endocrinol Metab 276: E710-715, 2005. 
Endurance training increases LKB1 and MO25 protein but not AMP-activated protein kinase kinase activity in skeletal muscle. Taylor EB, Hurst D, Greenwood LJ, Lamb JD, Cline TD, Sudweeks SN, Winder WW. Am J Physiol Endocrinol Metab. 287: E1082-9, 2004. 